$\overline{\text { Note }}$

\title{
Antifungal Activities of Plant Extracts against Some Aquatic Fungi
}

\author{
TSUYOSHI MORI ${ }^{\prime}$, HITOMI HIROSE ${ }^{1}$, CHUTIMA \\ HANJAVANIT $^{2,3}$ AND KISHIO HATAI ${ }^{3 *}$ \\ 'Laboratory of Aquatic Animals Health, Department of Marine Science and Resources, \\ College of Bioresource Sciences, Nihon University, Kameino 1866, Fujisawa-shi, \\ Kanagawa 252-0813, Japan, ${ }^{2}$ Biology Department, Faculty of Science, \\ Khon Kaen University, Khon Kaen 40002, Thailand and ${ }^{3}$ Division of Fish \\ Diseases, Nippon Veterinary and Animal Science University, \\ 1-7-1 Kyonan-cho, Musashino-shi, Tokyo 180-8602, Japan
}

Received 21 November 2001/Accepted 23 February 2002

\begin{abstract}
Hinokitiol, citral and allylisothiocyanate, which are chemicals of plant extracts, were investigated for their effectiveness as antifungal agents against the genera Saprolegnia, Aphanomyces and Achlya. The minimum inhibitory concentrations (MICs) of these chemicals were $12.5 \mu \mathrm{g} / \mathrm{ml}$ of hinokitiol against all fungal isolates, and $100.0-200.0 \mu \mathrm{g} / \mathrm{ml}$ of citral and $50.0-100.0 \mu \mathrm{g} / \mathrm{ml}$ of allylisothiocyanate were appeared to inhibit the growth of Saprolegnia and Aphanomyces, but not Achlya. Among these chemicals, $100.0 \mu \mathrm{g} / \mathrm{ml}$ of hinokitiol was the most effective agent to inhibit the hyphal growth of S. parasitica ATCC 90213 and Aphanomyces spp. but not of $S$. diclina ATCC 90215 and Achlya. Hinokitiol also inhibited at $100.0 \mu \mathrm{g} / \mathrm{ml}$ the zoospore germination of Saprolegnia spp., whereas $12.5-25.0 \mu \mathrm{g} / \mathrm{ml}$ of hinokitiol inhibited the zoospore germination of Aphanomyces spp. (but not Achlya). Treatment with a higher concentration of citral $(800.0 \mu \mathrm{g} / \mathrm{ml})$ had an effectiveness of inhibiting the hyphal growth of all fungal isolates but the zoospores of all isolated strains showed higher sensitivity to citral $(200.0-400.0 \mu \mathrm{g} / \mathrm{ml})$ than their vegetative stages did. The treatment with $100.0-400.0 \mu \mathrm{g} / \mathrm{ml}$ of allylisothiocyanate was found to inhibit the vegetative growth of all fungal isolates except Achlya. On the other hand, the zoospores of all isolates showed higher sensitivity to allylisothiocyanate $(200.0-400.0 \mu \mathrm{g} / \mathrm{ml})$ than their vegetative stages did.
\end{abstract}

Key words : Antifungal activity/Aquatic fungi/Allylisothiocyanate/Citral/Hinokitiol/Plant extracts.

Mycotic disease in freshwater fishes is usually caused by fungi in the family Saprolegniaceae, the genera Saprolegnia, Aphanomyces and Achlya (Hatai, 1980). The minimum inhibitory concentrations (MIC) of three chemicals, malachite green, formalin and sodium chloride $(\mathrm{NaCl})$, against those three genera were investigated (Yuasa and Hatai, 1995). The most effective chemical was malachite green, which inhibited zoospore germination and hyphal growth at

*Corresponding author. Tel and Fax : +81-422-31-6796 a low concentration. However, malachite green has teratogenic and carcinogenic properties (Merer and Jorgenson, 1983), so its use as a fungicide in fish culture is prohibited in the U.S. by the Food and Drug Administration (FDA) (Marking et al., 1994; Fitzpatrick et al., 1995). $\mathrm{NaCl}$ has been frequently used as a fungal control agent, but it is effective at only a high concentration, and its fungicidal activity is poor in comparison with malachite green (Hatai et al., 1977).

Recently, the use of extracts from plants for antibacterial purpose has spread because of their safety 
(Kobori and Tanabe, 1993, 1994a and b). Plant extracts, such as hinokitiol, citral and allylisothiocyanate, are widely used for the preservation of food and antibacterial treatment of household articles (Yokota et al., 1994). An objective of this study was to investigate the effectiveness of treatment with these plant extracts on the vegetative and zoosporic stages of three generic fungi, in comparison with those of treatments with malachite green, formalin and $\mathrm{NaCl}$.

Malachite green (including malachite green oxalate 99\% solution: Wako Pure Chemical Industries, Ltd.), formalin (Wako Pure Chemical Industries, Ltd.) , NaCl (Manaku, Ltd.), hinokitiol (Kanto Chemical Ltd.), citral (cis +trans: Wako Pure Chemical Industries, Ltd.) and allylisothiocyanate (SOH-Ei, Ltd.) were used as antifungal agents.

Details of fungal isolates used in the present study are presented in Table 1. The fungi, Saprolegnia, Aphanomyces and Achlya, were cultured in Petri dishes of glucose yeast (GY) media with $1.5 \% \mathrm{w} / \mathrm{v}$ agar (Difco) at $20^{\circ} \mathrm{C}$ to obtain vegetative hyphae, and edges of colonies were cut and put into GY broth before being transferred to sterilized tap water to obtain zoospores, as described by Hatai and Egusa (1979).

The antifungal agents used in this experiment were malachite green, formalin, $\mathrm{NaCl}$, hinokitiol, citral and allylisothiocyanate. The fungi, Saprolegnia, Aphanomyces and Achlya were cultured on $20 \mathrm{ml}$ of GY agar at $20^{\circ} \mathrm{C}$. Culturing was done for $2-3 \mathrm{~d}$ for Saprolegnia spp. and 5-6 d for Aphanomyces spp. and Achlya diffusa NJM 9228. Each chemical was mixed with $20 \mathrm{ml}$ of GY agar. The actively growing mycelia were cut off with a No. 2 Cork borer $(5.5 \mathrm{~mm}$ in dia.) and centrally placed onto the media. The effectiveness of the antifungal agents was determined by measuring the diameter of the colony"every 2 days for 6 days. Colony diameters of the fungi were measured at different times depending on the genus: diameter of Aphanomyces spp. were determined at day 6, that of Achlya diffusa NJM 9228 was determined at day 4 and those of Saprolegnia spp. at day 2. A control group for each fungus on GY agar without any antifungal agent was also observed.

The plant extracts used in this experiment were hinokitiol, citral and allylisothiocyanate. The chemicals were tested for their fungicidal activities against the vegetative and zoosporic stages. The activity against the vegetative stage was carried out as follows: the fungal isolates were prepared according to the culture conditions mentioned above. An actively growing part of each isolate was excised and placed into the various concentrations of the plant extracts for $10 \mathrm{~min}$, $30 \mathrm{~min}, 1 \mathrm{~h}, 2 \mathrm{~h}$ and $24 \mathrm{~h}$, respectively. Then it was washed twice with $40 \mathrm{ml}$ of sterilized distilled water and placed onto $20 \mathrm{ml}$ of GY agar without plant extracts. The effectiveness of the three plant extracts against the vegetative stages was determined by comparing colony diameters of the treated ones with those of the control group which had been immersed in sterilized distilled water. In the case that no growth of fungi appeared after $24 \mathrm{~h}$, the fungi were kept for $3 \mathrm{~d}$ to observe their viability.

The investigation of the activity of plant extracts against fungi in the zoosporic stage was conducted by preparing the 10-time-concentrated solution of the plant extract in sterilized distilled water. Zoospore production was carried out in sterilized tap water, after which they were harvested by aseptic filtration through gauze. The number of zoospores was evaluated and adjusted to $100-200$ spores $/ \mathrm{ml}$. Then $1 \mathrm{ml}$ of the concentrated solution prepared was added to $9 \mathrm{ml}$ of zoospore suspension and $500 \mu \mathrm{I}$ of the mixture was inoculated into $40 \mathrm{ml}$ of GY broth after $10 \mathrm{~min}, 30$ $\min , 1 \mathrm{~h}, 2 \mathrm{~h}$ and $24 \mathrm{~h}$. This dilution ratio had been determined by a preliminary test to show that there was no effect on the germination of viable zoospores. The viability of zoospores was determined by the appearance of germinating thalli during a 3-4 d period under the microscope. Control groups without the plant extract treatment were also observed. All of the experiments were performed at $20{ }^{\circ} \mathrm{C}$. The minimal

TABLE 1. The fungal isolates used in the present study.

\begin{tabular}{lcllll}
\hline Species & Isolate no. & Host/habitat $^{2}$ & Origin & Host location & Year isolated \\
\hline Saprolegnia parasitica & $\begin{array}{c}\text { ATCC 90213 } \\
\text { (NJM 8604) }\end{array}$ & Coho salmon & Fish surface & Miyagi & 1986 \\
Saprolegnia diclina & $\begin{array}{l}\text { ATCC 90215 } \\
\text { (NJM 8605) }\end{array}$ & Coho salmon & Fish surface & Miyagi & 1986 \\
Aphanomyces piscicida & $\begin{array}{l}\text { ATCC 32712 } \\
\text { (NJM 8997) }\end{array}$ & Ayu & Internal viscera & Tochigi & 1989 \\
Aphanomyces sp. & NAV 9201 & Nihon ishigame & Skin surface & Tokyo & 1992 \\
Achlya diffusa & NJM 9228 & Pond water & - & Tokyo & 1992 \\
\hline
\end{tabular}

${ }^{a}$ Coho salmon: Oncorynchus kisutch Walbaum; ayu: Plecoglossus altiwelis Temminct et Schligel; nihon ishigame: Mauremys japonica. 
concentration of each plant extract at which the growth of each fungus was inhibited, was expressed as MIC in these experiments.
As seen in Tables 2-3, the MICs of malachite green were $2.0 \mathrm{\mu} \mathrm{g} / \mathrm{ml}$ against S. parasitica ATCC 90213 and $1.0 \mathrm{\mu} \mathrm{g} / \mathrm{ml}$ against both S. diclina ATCC 90215

TABLE 2. Antifungal effects of malachite green, formalin and $\mathrm{NaCl}$ on the growth of three fungal genera.

\begin{tabular}{|c|c|c|c|c|c|}
\hline \multirow[b]{2}{*}{ Concentration } & \multicolumn{5}{|c|}{ Isolate } \\
\hline & $\begin{array}{l}\text { S. parasitica } \\
\text { ATCC } 90213\end{array}$ & $\begin{array}{c}\text { S. diclina } \\
\text { ATCC } 90215\end{array}$ & $\begin{array}{l}\text { A. piscicida } \\
\text { NJM } 8997\end{array}$ & $\begin{array}{c}\text { Aphanomyces sp. } \\
\text { NAV } 9201\end{array}$ & $\begin{array}{c}\text { Achlya diffusa } \\
\text { NJM } 9228\end{array}$ \\
\hline \multicolumn{6}{|l|}{ Control } \\
\hline $\begin{array}{c}0 \mu \mathrm{g} / \mathrm{ml} \\
\text { Malachite green }\end{array}$ & $100^{a}$ & 100 & 100 & 100 & 100 \\
\hline $0.5 \mu \mathrm{g} / \mathrm{ml}$ & 15.5 & 26.9 & 4.1 & 0.3 & 22.9 \\
\hline 1.0 & 5.2 & 0 & 0 & 0 & 17.5 \\
\hline 1.5 & 4.6 & 0 & 0 & 0 & 9.0 \\
\hline 2.0 & 0 & 0 & 0 & 0 & 10.0 \\
\hline 2.5 & 0 & 0 & 0 & 0 & 8.8 \\
\hline 3.0 & 0 & 0 & 0 & 0 & 7.9 \\
\hline \multicolumn{6}{|l|}{ Formalin } \\
\hline $12.5 \mu \mathrm{g} / \mathrm{ml}$ & 90.0 & 95.2 & 98.8 & 76.0 & 112.1 \\
\hline 25.0 & 85.5 & 87.0 & 60.7 & 0 & 79.8 \\
\hline 50.0 & 59.0 & 57.6 & 0 & 0 & 44.7 \\
\hline 100.0 & 0 & 0 & 0 & 0 & 0 \\
\hline \multicolumn{6}{|l|}{$\mathrm{NaCl}$} \\
\hline $0.5 \%$ & 105.3 & 86.0 & 64.4 & 78.2 & 78.6 \\
\hline 1.0 & 69.6 & 58.5 & 7.4 & 48.1 & 28.6 \\
\hline 1.5 & 42.2 & 43.0 & 0 & 4.7 & 0 \\
\hline 2.0 & 19.3 & 34.0 & 0 & 0 & 0 \\
\hline 2.5 & 0 & 13.7 & 0 & 0 & 0 \\
\hline 3.0 & 0 & 0 & 0 & 0 & 0 \\
\hline
\end{tabular}

${ }^{a}$ Percentage of the colony diameter on media containing different concentrations of malachite green, formalin and $\mathrm{NaCl}$ compared with the control group of each isolate.

TABLE 3. Antifungal effects of hinokitiol, citral and allylisothiocyanate on the growth of three fungal genera.

\begin{tabular}{|c|c|c|c|c|c|}
\hline \multirow[b]{2}{*}{ Concentration } & \multicolumn{5}{|c|}{ Isolate } \\
\hline & $\begin{array}{l}\text { S. parasitica } \\
\text { ATCC } 90213\end{array}$ & $\begin{array}{c}\text { S. diclina } \\
\text { ATCC } 90215\end{array}$ & $\begin{array}{l}\text { A. piscicida } \\
\text { NJM } 8997\end{array}$ & $\begin{array}{c}\text { Aphanomyces sp. } \\
\text { NAV } 9201\end{array}$ & $\begin{array}{c}\text { Achlya diffusa } \\
\text { NJM } 9228\end{array}$ \\
\hline \multicolumn{6}{|l|}{ Control } \\
\hline $\begin{array}{l}0 \mu \mathrm{g} / \mathrm{ml} \\
\text { Hinokitiol }\end{array}$ & $100^{a}$ & 100 & 100 & 100 & 100 \\
\hline $3.2 \mu \mathrm{g} / \mathrm{ml}$ & 88.2 & 102.6 & 98.0 & 99.3 & 128.0 \\
\hline 6.3 & 80.6 & 94.9 & 81.1 & 98.0 & 102.6 \\
\hline 12.5 & 0 & 0 & 0 & 0 & 0 \\
\hline 25.0 & 0 & 0 & 0 & 0 & 0 \\
\hline \multicolumn{6}{|l|}{ Citral } \\
\hline $12.5 \mu \mathrm{g} / \mathrm{ml}$ & 96.1 & 73.0 & 66.3 & 98.3 & 96.7 \\
\hline 25.0 & 85.0 & 71.8 & 45.7 & 97.3 & 113.1 \\
\hline 50.0 & 67.6 & 46.3 & 23.8 & 95.1 & 102.0 \\
\hline 100.0 & 53.0 & 6.5 & 0 & 69.9 & 43.9 \\
\hline 200.0 & 0 & 0 & 0 & 0 & 2.8 \\
\hline \multicolumn{6}{|c|}{ Allylisothiocyanate } \\
\hline $12.5 \mu \mathrm{g} / \mathrm{ml}$ & 93.1 & 97.2 & 94.3 & 109.2 & 122.2 \\
\hline 25.0 & 85.5 & 79.1 & 54.9 & 94.0 & 120.3 \\
\hline 50.0 & 83.2 & 90.4 & 0 & 85.2 & 116.7 \\
\hline 100.0 & 0 & 0 & 0 & 0 & 27.9 \\
\hline
\end{tabular}

${ }^{a}$ Percentage of the colony diameter on media containing different concentrations of hinokitiol, citral and allylisothiocyanate compared with the control group of each isolate. 
TABLE 4. Effect of the dosage of hinokitiol, citral, and allylisothiocyanate on the vegetative growth and zoospore germination of tested fungi exposed for $60 \mathrm{~min}$.

\begin{tabular}{llll}
\hline & & \multicolumn{2}{c}{ MIC } \\
\cline { 2 - 3 } Plant extracts & Isolates & $\begin{array}{l}\text { Vegetative } \\
\text { growth }\end{array}$ & $\begin{array}{l}\text { Zoospore } \\
\text { germination }\end{array}$ \\
\hline Hinokitiol & Saprolegnia parasitica ATCC90213 & $100^{a}$ & 100 \\
& Saprolegnia diclina ATCC90219 & $>100$ & 100 \\
& Aphanomyces piscicida NJM8997 & 100 & $<12.5$ \\
& Aphanomyces sp. NAV9201 & 100 & 25 \\
& Achlya diffusa NJM 9228 & $>100$ & $>100$ \\
Citral & Saprolegnia parasitica ATCC90213 & 800 & 400 \\
& Saprolegnia diclina ATCC90219 & 800 & 400 \\
& Aphanomyces piscicida NJM8997 & 800 & 200 \\
& Aphanomyces sp. NAV9201 & 800 & 400 \\
& Achlya diffusa NJM 9228 & 800 & 400 \\
Allylisothiocyanate & Saprolegnia parasitica ATCC90213 & 400 & 200 \\
& Saprolegnia diclina ATCC90219 & 400 & 400 \\
& Aphanomyces piscicida NJM8997 & 400 & 100 \\
Aphanomyces sp. NAV9201 & 200 & 200 \\
Achlya diffusa NJM 9228 & $>800$ & 400 \\
\hline
\end{tabular}

${ }^{a} \mu \mathrm{g} / \mathrm{ml}$.

and Aphanomyces spp., whereas no concentrations of malachite green had any effect on the fungal growth of Achlya diffusa NJM 9228. The MICs of formalin were $100.0 \mathrm{\mu g} / \mathrm{ml}$ against both Saprolegnia spp. and Achlya diffusa NJM 9228; $50.0 \mathrm{\mu} \mathrm{g} / \mathrm{ml}$ against $A$. piscicida NJM 8997 and $25.0 \mu \mathrm{g} / \mathrm{ml}$ against Aphanomyces sp. NAV 9201. The MICs of $\mathrm{NaCl}$ were 2.5\% against S. parasitica ATCC 90213; $3.0 \%$ against $S$. diclina ATCC 90215; 1.5\% against both A. piscicida NJM 8997 and Achlya diffusa NJM 9228, whereas it was 2.0\% against Aphanomyces sp. NAV 9201. The MIC of hinokitiol was $12.5 \mu \mathrm{g} / \mathrm{ml}$ against all fungal isolates used. The MICs of citral were $200.0 \mathrm{\mu g} / \mathrm{ml}$ against both Saprolegnia spp. and Aphanomyces sp. NAV 9201; $100.0 \mathrm{\mu} \mathrm{g} / \mathrm{ml}$ against $A$. piscicida NJM 8997, whereas no concentrations of citral had any effect on Achlya diffusa NJM 9228. The MICs of allylisothiocyanate were $100.0 \mu \mathrm{g} / \mathrm{ml}$ against both Saprolegnia spp. and Aphanomyces sp. NAV 9201; $50.0 \mu \mathrm{g} / \mathrm{ml}$ against $A$. piscicida NJM 8997 but there was no affect on Achlya diffusa NJM 9228.

As shown in Table 4, the treatment with $100 \mu \mathrm{g} / \mathrm{ml}$ of hinokitiol was effective in killing both the hyphae and zoospores of S. parasitica ACTT 90213, but it only killed the zoospores of $S$. diclina ATCC 90215 and hyphae of both $A$. piscicida NJM 8997 and Aphanomyces sp. NAV 9201. The zoospores of $A$. piscicida NJM 8997 and Aphanomyces sp. NAV 9201 were more sensitive to hinokitiol $(12.5 \mu \mathrm{g} / \mathrm{ml}$ and $25.0 \mathrm{\mu g} / \mathrm{ml}$, respectively) than their hyphae, whereas both stages of Achlya diffusa NJM 9228 had a high tolerance to hinokitiol. The treatment with citral at the highest concentration of $800.0 \mu \mathrm{g} / \mathrm{ml}$ was effective in killing the vegetative stages of all fungal strains used (Table 4). On the other hand, $400.0 \mu \mathrm{g} / \mathrm{ml}$ of citral could kill the zoospores of almost all fungal strains tested, and A. piscicida NJM 8997 showed an even a higher sensitivity to citral $(200.0 \mathrm{\mu} \mathrm{g} / \mathrm{ml})$ (Table 4). The treatment of $400.0 \mu \mathrm{g} / \mathrm{ml}$ of allylisothiocyanate was effective in killing the vegetative stage of $S$. parasitica ACTT 90213 but its zoosporic stage was more sensitive than its vegetative stage. The concentrations of $400.0 \mu \mathrm{g} / \mathrm{ml}$ and $200.0 \mu \mathrm{g} / \mathrm{ml}$ of allylisothiocyanate were also effective in killing both stages of S. diclina ATCC 90215 and Aphanomyces sp. NAV 9201, respectively. The hyphae of $A$. piscicida NJM 8997 showed higher sensitivity to allylisothiocyanate than its zoospores. Various concentrations of allylisothiocyanate was not effective in killing the vegetative stages of $A$. diffusa NJM 9228, whereas the concentration of $200.0 \mu \mathrm{g} / \mathrm{ml}$ was able to kill its zoospores (Table 4).

Malachite green, formalin and $\mathrm{NaCl}$ have been reported as antifungal agents in the culturing of fish and fish eggs; namely $2.0 \mu \mathrm{g} / \mathrm{ml}$ of malachite green, $125.0 \mathrm{\mu} \mathrm{g} / \mathrm{ml}$ of formalin and $2.5 \%$ of $\mathrm{NaCl}$ were effective in controlling fungal infection (Kitancharoen and Hatai, 1998; Yuasa and Hatai, 1995). The result of the present study is similar to those of Yuasa and Hatai (1995) and Kitancharoen and Hatai (1998). It demonstrated that the range of concentrations of chemicals that had an effectiveness in inhibiting the growth 
of the genera Saprolegnia, Aphanomyces and Achlya was as follows: $1.0-2.0 \mu \mathrm{g} / \mathrm{ml}$ of malachite green (except against Achlya); $25.0-100.0 \mu \mathrm{g} / \mathrm{ml}$ of formalin and $1.5-3.0 \%$ of $\mathrm{NaCl}$.

Kobori and Tanabe $(1993,1994 a$ and b) reported that the chemical extracts from plants could be used as antibacterial and bactericidal agents. According to Yokota et al. (1994), plant extracts, e.g. hinokitiol, generally were used in hair tonic and cosmetics; citral was used as an aromatic agent in medicine and had a potential bactericidal action against pathogenic bacteria; allylisothiocyanate is used to preserve the freshness of food. Matsumoto et al. (1994) reported that a concentration of $50.0-200.0 \mathrm{\mu} \mathrm{g} / \mathrm{ml}$ of hinokitiol was the MIC against bacteria. The present results showed that a lower concentration of hinokitiol, $12.5 \mathrm{\mu} \mathrm{g} / \mathrm{ml}$, was effective in inhibiting the growth of hyphae of the genera Saprolegnia, Aphanomyces and Achlya. Therefore, fungi in the family Saprolegniaceae were more sensitive to hinokitiol than bacteria were. Other plant extracts, i.e. citral and allylisothiocyanate, were also used as antifungal agents in this study. In a comparison study, it was shown that a concentration of $50.0 \mathrm{\mu} \mathrm{g} / \mathrm{ml}$ of allylisothiocyanate appeared to be more effective in inhibiting growth of A. piscicida NJM 8977 than $100.0 \mu \mathrm{g} / \mathrm{ml}$ of citral. Also $100.0 \mu \mathrm{g} / \mathrm{ml}$ of allylisothiocyanate had a greater effectiveness in inhibiting the growth of both Saprolegnia spp. and Aphanomyces sp. NAV 9201 than $200.0 \mu \mathrm{g} / \mathrm{ml}$ of citral. However, the high concentrations of $100.0 \mathrm{\mu g}$ $/ \mathrm{ml}$ of citral and $200.0 \mathrm{\mu g} / \mathrm{ml}$ of allylisothiocyanate had no effect in inhibiting the hyphal growth of Achlya diffusa NJM 9228. The effectiveness of plant extracts in inhibiting hyphal growth may be dependent on the toxicity of plant extracts. Furthermore, the zoospores of these genera were more sensitive to the plant extracts than the hyphae were. The zoospore is a single cell, which is easily to vulnerable to plant extracts, and the zoospore stage is important in the development of saprolegniasis in fish (Willoughby and Pickering, 1977). This is the first report to demonstrate the sensitivities of the plant extracts to control the hyphal growth and zoospore germination of fungi, family Saprolegniaceae in vitro. However, it is necessary to investigate the efficacy of these plant extracts in controlling naturally occurring fungal infections in fish and fish eggs.

\section{REFERENCES}

Fitzpatrick, M. S., Schreck, C.B., Chitwood, R.L., and Marking, L. L. (1995) Evaluation of three candidate fungicides for treatment of adult spring chinook salmon. Prog. Fish-Cult., 57, 153-155.

Hatai, K., Egusa, S., Takahashi, S., and Ooe, K. (1977) Study on the pathogenic fungus mycotic granulomatosis-l. Isolation and pathogenicity of the fungus from culturedayu infected with the disease (in Japanese). Fish Pathol., 12, 129-133.

Hatai, K., and Egusa, S. (1979) Studies on the pathogenic fungus of mycotic granulomatosis- III. Development of the medium for MG-fungus (in Japanese). Fish Pathol., 13, 147-152.

Hatai, K. (1980) Saprolegniasis in Salmonids (in Japanese). Fish Pathol., 14, 199-206.

Kitancharoen, N. and Hatai, K. (1998) Effects of Sodium Chloride, Hydrogen Peroxide and Malachite Green on Fungal Infection in Rainbow Trout Eggs. Biocontrol Sci., 3, 113-115.

Kobori, K., and Tanabe, T. (1993) Antimicrobial activity of Hinokitiol for methicillin resistant Staphylococcus aureus. 1 (in Japanese). Med. Examinat., 42, 1639-1642.

Kobori, K., and Tanabe, T. (1994a) Antimicrobial activity of Hinokitiol for methicillin resistant Staphylococcus aureus. 2 (in Japanese). Med. Examinat., 43, 15-20.

Kobori, K., and Tanabe, T. (1994b) Antimicrobial activity of Hinokitiol for methicillin resistant Staphylococcus aureus. 3 (in Japanese). Med. Examinat., 43, 21-25.

Marking, L. L., Rach, J. J.,, and. Schreier, T. M. (1994) Evaluation of antifungal agents for fish culture. Prog. FishCult., 56, 225-231.

Matsumoto, S., Fukui, T., Terasaki, S., Yoshinaka, S., Hasegawa, A., Okabe, T., Saito, K., and linuma, K. (1994) Antibacterial activities of metal chelates of Hinokitiol (in Japanese). J. Antibact. Anitifung. Agents, 22, 265-269.

Merer, F. P., and Jorgenson, T. A. (1983) Teratological and other effects of malachite green on the development of rainbow trout and rabbits. Trans. Amer. Fish. Soc., 112, 812-824.

Willoughby, L. G., and Pickering, A. D. (1977) Viable Saprolegniaceae spores on the epidermis of the salmonid fish Salmo trutta and Salvelnus alpiuns. Trans. Br. Mycol., 68, 91-95.

Yuasa, K., and Hatai K. (1995) Drug sensitivity of some pathogenic water moulds isolates from freshwater fishes (in Japanese). J. Antibact. Antifung. Agents, 23, 213-219.

Yokota, M., Tatsumi, N., and Tsuda, I. (1994) Antimicrobial effect of aromatic natural compound, chiefly against Staphylococcus aureus. Med. Biol., 128, 105-110. 